\title{
A Study on Somatotype Profiles of the Players in Turkish Bocce National Team
}

\author{
Nebahat Eler ${ }^{1}$, Serdar Eler ${ }^{2}$ \\ ${ }^{1}$ Physical Education and Sports High School, Bulent Ecevit University, Zonguldak, Turkey \\ ${ }^{2}$ Faculty of Sports Sciences, Gazi University, Ankara, Turkey \\ Correspondence: Nebahat Eler, Physical Education and Sports High School, Bulent Ecevit University, Zonguldak, \\ Turkey.
}

Received: December 7, 2017

doi:10.11114/jets.v6i2.2940
Accepted: January 10, $2018 \quad$ Online Published: January 20, 2018

URL: https://doi.org/10.11114/jets.v6i2.2940

\begin{abstract}
The aim of this study is to determine the differences between the somatotype profiles and inter-disciplinary somatotype profiles of the Turkish Bocce National Team players. In this study, the mean age of the Turkish Men's Bocce National Team (n-32) was determined as 21,75 $\pm 2,35$ (years), mean height was $177,62 \pm 1,03(\mathrm{~cm})$, mean body weight was $70,75 \pm 0,70(\mathrm{~kg})$, mean Body Mass Index (BMI) was $22,31 \pm 1,06 \mathrm{~kg} / \mathrm{m}^{2}$, mean body fat percentage was $16,05 \pm 1 \%$. The mean age of the Turkish Women's Bocce National Team (n-21) was 21,76 $\pm 2,12$ (years), mean height was 165,33 $\pm 4,24$ $(\mathrm{cm})$, mean body weight $55,14 \pm 6,36(\mathrm{~kg})$, mean BMI was $23,22 \pm 1,06 \mathrm{~kg} / \mathrm{m}^{2}$ mean body fat percentage was $16,05 \pm 1 \%$. The Heath-Carter method was used in determining the somatotype profiles of the players. the The statistical analyses in the study were made by using the SPSS 20.0 package program. Somatotype profile in men was determined endomorphic $3,21 \pm 0,33$; mesomorph 5,04 $\pm 1,11$; ectomorphic $2,20 \pm 0,18$ as mesomorphic-endomorphic; in women, endomorphic $3,33 \pm 1,42$; mesomorph 5,08 $\pm 0,26$; ectomorphic $2,07 \pm 0,09$ as mesomorphic-endomorphic. In this study, the somatotype profiles of the Turkish Bocce National Team players were determined, and a statistically significant difference was detected between the volo and petanque-raffa disciplines in men and women $(\mathrm{p}<0,05)$. It is believed that this difference stems from the physical performance requiring more muscular force in volo discipline than the petanque and raffa disciplines. In this study, the somatotype components are similar in tennis players in volo men group and the archers, judo players and Water polo players of the other groups (Men-women petanque and raffa group, Women volo group).
\end{abstract}

Keywords: Somatotype, bocce, volo, men, women

\section{Introduction}

The history of Bocce dates back, is based on competition, and is becoming more and more popular. Bocce players may be from any age and gender groups. It has a recreative purpose and is a competitor sport. There is an increasing physical and mental challenge in it. It is leant easily due to its extremely clear instructions (Pagnoni, M., 2010). Some games that are similar to Bocce has existed since very old times in history. With a general description, it is possible to claim that the antique games that have the purpose of throwing balls or similar materials and hitting a target or closing to a target re the ancestors of Bocce, Petanque, Lawn Ball and even Bowling (Türkmen, M., 2011). The first system played in our country was the Raffa System, and was developed by Italians. It is generally named as Bocce. The game system that is called as Raffa in our country and in international arena is defined as Bocce in Italian language. The game system that is known as Volo in our country is defined as Sport Boules or Boule Lyonnaise (since it was born in Lyon Region) in French. In Italian language, the term Volo is used for the same games. The name of the international federation of this system is defined as La Fédération Internationale de Boules-FIB in French. It is used to include another French-originated game, Petanque. Petanque is the most common system in the whole world, and is called and learn with its own name in many countries (Pagnoni, M., 2010). The term Bocce is used in our country for 4 different sports branches, which are Raffa, Petanque, Volo and Lawn Ball. The World Bocce Sports Confederation was established in Monaco on December 21, 1985, and was recognized officially in International Olympics Committee (IOC), which convened in Lausanne on October 15, 1986. Today, the disciplines of Bocce are played almost in any region of the world in a common manner. In our country, Bocce had its own confederation in 2005. In time, the term Bocce was used to mean the 4 games, Raffa, Volo, Petanque and Lawn Ball. In 2006, Interclub Turkey Bocce Leagues for men and 
women were started for the first time. As of 2006, Bocce became more and more widespread, and had its place in international competitions. As of 2008, a successful period started (Türkmen, M., 2011).

The popularity of Bocce game increased in our country and in the whole world, it is limited with petanque raffa and volo throwing systems, and played in a smooth field with synthetic Bocce balls. Bocce is played in single, double and triple categories (these are called as traditional categories) (Turkmen, M., 2013). Small balls called marble and big balls called pallino are also used with different purposes. In Raffa, the hitting and approach throws are made with balls. Approach (Punto) is performed with the throw of a player to approach to a previously thrown ball or marble in the field. The purpose of a player in Volo is throwing the ball closer to a small target ball called marble. The other player tries to go nearer to that ball with his/her ball when his/her turn comes or removes the ball of his/her opponent that prevents his/her ball to approach the target ball. The running series makes Volo Discipline different from the others. The game is played as approaching the balls to each other (Punto) or determining the big and small balls to be hit and with Raffa and Volo throw and removal methods. In this way, players continue the game with one or more balls and try to get the highest point (Turkmen, M., 2011).

After a certain training period, the automatization of the movements, and flexibility in mental terms are desired features in a Bocce player (Pagnoni, M., 2010). The player will acquire basic skills and applicable knowledge in Bocce. Bocce is sports branch in which aerobic-anaerobic force capacity, endurance, force and Body composition are dominant (Turkmen et al., 2013).

Somatotype technique is a universal technique applied in assessing the shape and structure of the body. The body composition characterizes the metabolism level and the predisposition to certain diseases, and in one sense, it is the indispensable property of the morphological status of a person. Somatotype studies ensures that the physical properties of people are defined and compared in various societies (Andreenko, E. and Mladenova, C). Somatotype technique was first applied as based on body shape and volume in 1940 by Sheldon. Then, the modified somatotype method of Heath and Carter was used more frequently (Duquet et al., 1977) (Carter L. J. E., 1985). Somatotype means the definition of the morphological structure of the body, and classifies the human body as three basic components, which are endomorphic, mesomorph and ectomorphic. Endomorphic is related with the fat rate of the body being high; mesomorph is related with the developed and strong skeleton-muscle structure; ectomorphic is related with the weakness of the skeleton-muscle structure (Carter and Heat, 1990) (Özer, K., 1993).

It has been considered for long years that a proper body type plays important role in sportive performance (Zorba and Ziyagil, 1995) (Bektaş et al., 2007) (Sharma and Dixit, 1995). Studies reveal that there are major differences in the physical structures of the players in various sports branches (Parizkova, J., 1968). We have observed various comments on body structure since ancient times. The innate body structure is influential on sportive performance as well as long term physical workouts, which cause changes in physical structure (Zorba, E., 2012). Studies have revealed major changes in body structures of players in different sports branches (Bektaş et al., 2007). On the other hand, body structure influences and changes activity. For example, a high body structure is not advantageous in activities that require lifting and carrying loads. Activities like tennis and fencing cause asymmetry in somatotype development. If the player uses his/her right arm in general, the right arm has a bigger diameter than the left arm. Muscular, hard and strong body structure reveal itself in players who play basketball, volleyball, and football (Zorba, E., 2012). Despite the different applications in examining the relations between physical abilities and somatotype, generally, the effects of positive mesomorph points and negative endomorphic points on physical abilities are pointed out. It has been revealed in previous studies with endurance, fast force, force and speed performance tests that the mesomorph point is positively related, and endomorphic point is negatively related (Gürses and Ogun, 1991).

In elite sports, performance and success are affected by many factors and certain properties like the genetical structures, fitness, motor and mental skills, tactical training or anthropometry of the players (Carter and Heat, 1990). The body structure, in other words, physical properties, which affect performance, also affect the revealing of physiological capacities. As long as the property of the physical structure is not suitable for the sports branch, the desired performance level is not possible. Physical structure is one of the basic elements of high performance of a player. Force affects the performance of a player by combining with flexibility, speed, endurance, and agility (Ayan et al., 2011). Trainers and sports scientists collect objective data to confirm the aims of the trainings, to prepare short and long-term training programs, provide motivation during the training, receive unbiased feedback and to know the physical performance capacities of the players (Ball et al., 2011) (Kim et al., 2011). The data obtained with the physical performance tests may be used to determine the strong and weak sides of the individuals, to monitor the player in time, and to confirm the efficiency of training interventions. These types of data may also be useful to determine the physical properties of players, which are needed for success (Bridge et al., 2014).

There are many studies on somatotype and anthropometric properties in different branches [basketball (Carter et al., 2005). 
(Bektaş et al., 2007), handball (Sibila \& Pori, 2009), volleyball (Matilas et al., 2014) taekwondo (Bridge et al., 2014)]; however, as a result of the literature review we made, we observed that studies on somatotype profiles in Bocce are extremely rare both in the world and in our country.

\section{Methodology}

\subsection{Sample}

National Bocce Team players (Women- $n=21$, Men- $n=32$ ) from different disciplines playing in competitions in 2016 participated in this study (Table 1).

Table 1. Physical features of the Turkish men-women bocce national team players

\begin{tabular}{llllll}
\hline & Age (year) & Height $(\mathrm{cm})$ & Weight $(\mathrm{kg})$ & BMI kg/m2 & Body Fat \% \\
\hline Volo Men $(\mathrm{n}=16)$ & $22,25 \pm 2,57$ & $176,68 \pm 2,12$ & $68,37 \pm 2,83$ & $21,68 \pm 1,99$ & $14,58 \pm 2,57$ \\
Petanque-Raffa Men $(\mathrm{n}=16)$ & $21.25 \pm 2.79$ & $178,56 \pm 8,49$ & $73,13 \pm 9,19$ & $22,94 \pm 3,39$ & $17,53 \pm 5,98$ \\
Volo Women $(\mathrm{n}=11)$ & $22.27 \pm 4,24$ & $165,90 \pm 7,02$ & $54,09 \pm 2,83$ & $22,82 \pm 2,00$ & $16,85 \pm 2,26$ \\
Petanque-Raffa Women $(\mathrm{n}=10)$ & $21 \pm 2.12$ & $164,70 \pm 5,65$ & $56,30 \pm 7,07$ & $23,63 \pm 2,38$ & $17,86 \pm 1,06$ \\
\hline
\end{tabular}

2.2 Procedure

The Siri formula was applied to determine the body fat percentage, and the Durnin-Womersley formula was made use of to determine the body intensity, which was required to calculate the Siri Formula. The Heath-Carter Formula was used to determine the Somatotype profiles.

Durnin-Womersley body intensity formula:

Men

Women

$\mathrm{BD}=1.1620-0.0630 \times \mathrm{X}$ (Men 17-19 Years)

$\mathrm{BD}=1.1549-0.0678 \times \mathrm{X}$ (Women 17-19 Years)

$\mathrm{BD}=1.1631-0.0632 \times \mathrm{X}$ (Men 20-29 Years)

$\mathrm{BD}=1.1599-0.0717 \times \mathrm{X}$ (Women 20-29 Years)

$\mathrm{BD}=1.1422-0.0544 \times \mathrm{X}$ (Men 30-39 Years)

$\mathrm{BD}=1.1423-0.0632 \times \mathrm{X}$ (Women 30-39 Years)

Siri Formula: $\%$ Fat $=(4.95 / B D-4.50) \times 100$

Heath-Carter Formula:

Endomorphic $=0.7182+(0.1451 \mathrm{X} 1)-(0.00068 \mathrm{X} 2)+(0.0000014 \mathrm{X} 3)$

$\mathrm{X} 1=$ Triceps + Subscapular + Suprailiac skinfold thickness

$\mathrm{X} 2=(\text { Triceps }+ \text { Subscapular }+ \text { Suprailiac skinfold thickness })^{2}$

$\mathrm{X} 3=(\text { Triceps }+ \text { Subscapular }+ \text { Suprailiac skinfold thickness })^{3}$

Mesomorphic $=0.858(\mathrm{E})+0.601(\mathrm{~K})+0.188(\mathrm{~A})+0.161(\mathrm{C})-0.131(\mathrm{H})+4.5$

$\mathrm{E}=$ Humerus diameter

$\mathrm{K}=$ Femur diameter

$\mathrm{A}=$ Corrected arm circumference: arm circumference $(\mathrm{cm})-($ triceps dkk/10) $(\mathrm{mm})$

$\mathrm{C}=$ Corrected calf circumference: calf circumference $(\mathrm{cm})-($ calf $\mathrm{dkk} / 10)(\mathrm{mm})$

$\mathrm{H}=$ Height

Ectomorphic: Ectomorphic Component is obtained by finding the ponderal index (RPI).

RPI=

Height $(\mathrm{cm})$

$$
3 \sqrt{ } \text { Weight }(\mathrm{kg})
$$

If RPI if found higher than 40.75 , the following formula is used:

Ectomorphic $=0.732$ RPI -28.58

If RPI is equal to or lower than 40.75 , the following formula is used:

Ectomorphic $=0.463$ RPI -17.63

If RPI is equal to or lower than 38.25 , ectomorphic is calculated as 0.1 .

Holtain-brand anthropometric set was used for the measurements. The weights of the players were measured with a digital scale with $0,1 \mathrm{~kg}$ sensitivity; the heights were measured with a scale with $0.01 \mathrm{~m}$ sensitivity, BMI (Body Mass 
Index) was measured with Body Weight $(\mathrm{kg}) /$ Height $\left(\mathrm{m}^{2}\right)$ formula. The skinfold thickness, femur bicondylar and humerus bicondylar diameter measurements calf and biceps (flexion) circumference measurements were measured in biceps, triceps, subscapular, Suprailiac, and calf areas (Zorba, E., 2012) (Günay et al., 2013).

\subsection{Data Collection and Data Analysis}

The statistical analyses in the study were made by using the SPSS 20.0 package program. In order to determine the age differences between the groups, the t-test was applied in the independent groups. The significance level was accepted as $\mathrm{p}<0.05$.

\section{Results}

32 Men and 21 Women players participated in the study, and the mean physical measurement and somatotype values are given in Tables 2.3. According to the results, the somatotype profile of the Turkish National Team is mesomorphic-endomorphic.

Table 2. Physical features and somatotype values of men and women players

\begin{tabular}{l|llllll}
\hline & Age (year) & Height $(\mathrm{cm})$ & Weight(kg) & Endomorphy & Mesomorphy & Ectomorphy \\
\hline Men (n-32) & $21,75 \pm 2,35$ & $177,62 \pm 1,03$ & $70,75 \pm 0,70$ & $3,21 \pm 0,33$ & $5,04 \pm 1,11$ & $2,20 \pm 0,18$ \\
\hline Women (n-21) & $21,76 \pm 2,12$ & $165,33 \pm 4,24$ & $55,14 \pm 6,36$ & $3,33 \pm 1,42$ & $5,08 \pm 0,26$ & $2,07 \pm 0,09$ \\
\hline
\end{tabular}

Table 3. Distribution of somatotype values of male players in volo and petanque-raffa discipline

\begin{tabular}{llll|lll}
\hline & \multicolumn{3}{c|}{ Volo Discipline } & \multicolumn{3}{c}{ Petanque-Raffa Discipline } \\
\cline { 2 - 7 } $\mathrm{n}$ & Endomorphy & Mezomorphy & Ektomorphy & Endomorphy & Mezomorphy & Ektomorphy \\
\hline 1 & 2,69 & 5,77 & 2 & 3,72 & 3,62 & 2,23 \\
2 & 2,21 & 5,3 & 2,35 & 4,21 & 4,31 & 2 \\
3 & 2,21 & 4,31 & 2,65 & 3,24 & 4,36 & 1,76 \\
4 & 1,63 & 5,18 & 2 & 4,75 & 5,82 & 2,11 \\
5 & 2,37 & 5,14 & 2,8 & 5,13 & 4,85 & 2,13 \\
6 & 1,68 & 4,97 & 2,65 & 4,79 & 3,84 & 3,26 \\
7 & 2,24 & 5,74 & 2,36 & 2,36 & 5,28 & 2,33 \\
8 & 2,63 & 5,22 & 1,84 & 4,87 & 3,46 & 2 \\
9 & 1,14 & 6,23 & 2,17 & 4,21 & 4,71 & 2,73 \\
10 & 4,17 & 6,23 & 2,26 & 3,27 & 4,63 & 1,91 \\
11 & 2,58 & 4,96 & 2,75 & 4,78 & 5,29 & 2,36 \\
12 & 2,21 & 5,25 & 2,38 & 3,85 & 5,2 & 1,32 \\
13 & 2,27 & 5,64 & 1,68 & 4,36 & 5,68 & 2 \\
14 & 3,64 & 5,31 & 2,14 & 3,08 & 5,8 & 1,95 \\
15 & 1,84 & 5,28 & 1,67 & 3,48 & 3,89 & 2 \\
16 & 3,25 & 5,2 & 1,74 & 3,84 & 4,86 & 2,98 \\
\hline
\end{tabular}

Table 4. Distribution of somatotype values of women players in volo and petanque-raffa discipline

\begin{tabular}{llll|lll}
\hline & \multicolumn{3}{c|}{ Volo Discipline } & \multicolumn{3}{c}{ Petanque-Raffa Discipline } \\
\cline { 2 - 6 } $\mathrm{n}$ & Endomorphy & Mezomorphy & Ektomorphy & Endomorphy & Mezomorphy & Ektomorphy \\
\hline 1 & 2,76 & 6,12 & 1,69 & 3,86 & 4,23 & 1,71 \\
2 & 3,21 & 5,34 & 1,73 & 2,87 & 3,84 & 2,24 \\
3 & 1,85 & 5,71 & 2,23 & 3,84 & 5,7 & 2,32 \\
4 & 2,74 & 4,8 & 2,24 & 2,59 & 5,18 & 2,29 \\
5 & 2,04 & 6,2 & 1,82 & 4,85 & 5,27 & 1,78 \\
6 & 2,63 & 6,39 & 2 & 3,73 & 5,14 & 1,63 \\
7 & 3,17 & 4,21 & 1,68 & 5,14 & 3,95 & 2,08 \\
8 & 3,18 & 6,2 & 2,41 & 4,31 & 4,34 & 2,31 \\
9 & 2,87 & 4,76 & 2,56 & 5,94 & 4,41 & 2,18 \\
10 & 1,83 & 5,1 & 2,36 & 4,74 & 5,12 & 2,35 \\
11 & 1,84 & 4,6 & 1,85 & & &
\end{tabular}

Table 5. Somatotype values of Turkey bocce national team players

\begin{tabular}{l|lll}
\hline & Endomorphy & Mezomorphy & Ektomorphy \\
\hline Volo Men $(\mathrm{n}=16)$ & $2,42 \pm 0,39$ & $5,35 \pm 0,40$ & $2,21 \pm 0,18$ \\
Petanque-Raffa Men $(\mathrm{n}=16)$ & $3,99 \pm 0,08$ & $4,72 \pm 0,88$ & $2,19 \pm 0,53$ \\
Volo Women $(\mathrm{n}=11)$ & $2,55 \pm 0,65$ & $5,40 \pm 1,07$ & $2,05 \pm 0,11$ \\
Petanque-Raffa Women $(\mathrm{n}=10)$ & $4,18 \pm 1,38$ & $4,71 \pm 0,9$ & $2,08 \pm 0,45$ \\
\hline
\end{tabular}




\subsection{Comparison of Measurements in Men}

The t-test in independent groups was applied to determine whether the difference between the averages of petanque raffa and volo groups in men, and the results are given in Table 9.

Table 6. Comparison of measurements in men

\begin{tabular}{|c|c|c|c|c|c|c|}
\hline & & $\mathrm{n}$ & Average & Std. Dev. & $\mathrm{t}$ & $\mathrm{p}$ \\
\hline \multirow{2}{*}{ BMI $\left(\mathrm{kg} / \mathrm{m}^{2}\right)$} & Petanque Raffa & 16 & 22,94 & 3,39 & \multirow{2}{*}{1,29} & \multirow{2}{*}{0,207} \\
\hline & Volo & 16 & 21,68 & 1,99 & & \\
\hline \multirow{2}{*}{ Body Fat $\%$} & Petanque Raffa & 16 & 17,53 & 3,36 & \multirow{2}{*}{3,349} & \multirow{2}{*}{$0,002 *$} \\
\hline & Volo & 16 & 14,58 & 1,03 & & \\
\hline \multirow{2}{*}{ Endomorphy } & Petanque Raffa & 16 & 4 & 0,78 & \multirow{2}{*}{5,777} & \multirow{2}{*}{0,000 * } \\
\hline & Volo & 16 & 2,42 & 0,76 & & \\
\hline \multirow{2}{*}{ Mezomorphy } & Petanque Raffa & 16 & 4,73 & 0,76 & \multirow{2}{*}{$-2,804$} & \multirow{2}{*}{$0,009 *$} \\
\hline & Volo & 16 & 5,36 & 0,48 & & \\
\hline \multirow{2}{*}{ Ektomorphy } & Petanque Raffa & 16 & 2,19 & 0,47 & \multirow{2}{*}{$-0,153$} & \multirow{2}{*}{0,879} \\
\hline & Volo & 16 & 2,22 & 0,38 & & \\
\hline
\end{tabular}

* $\mathrm{p}<0,05$

According to the t-test in independent groups results; the body fat, endomorphic and mesomorph measurements in men, showed difference at a significant level when compared with the petanque-raffa and volo groups $(p<0,05)$; the other measurements do not differ at a significant level in the groups $(p>0,05)$. While the averages of the petanque raffa group for body fat and endomorphic measurements, which showed significant difference, were higher than the volo group at a significant level; the mean mesomorph value in volo group is different from the mean petanque raffa values at a significant level. For the other measurements, no significant differences exist between the petanque raffa and volo groups.

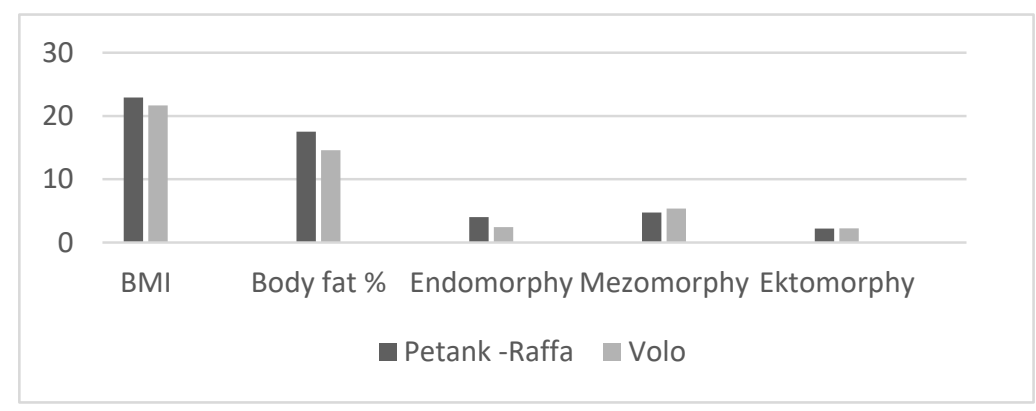

Graphic 1. Comparison of measurements in men.

\subsection{Comparison of Measurements in Women}

The t-test in independent groups was applied to determine whether the difference between the averages of petanque raffa and volo groups in women, and the results are given in Table 10.

Table 7. Comparison of measurements according to the groups in women

\begin{tabular}{|c|c|c|c|c|c|c|}
\hline & & $\mathrm{n}$ & Average & Std. Dev. & $\mathrm{t}$ & $\mathrm{p}$ \\
\hline \multirow{2}{*}{ BMI $\left(\mathrm{kg} / \mathrm{m}^{2}\right)$} & Petanque Raffa & 10 & 23,63 & 2,38 & \multirow{2}{*}{1,727} & \multirow{2}{*}{0,1} \\
\hline & Volo & 11 & 22,84 & 2 & & \\
\hline \multirow{2}{*}{ Body Fat $\%$} & Petanque Raffa & 10 & 18,26 & 1,92 & \multirow{2}{*}{1,757} & \multirow{2}{*}{0,095} \\
\hline & Volo & 11 & 16,77 & 1,95 & & \\
\hline \multirow{2}{*}{ Endomorphy } & Petanque Raffa & 10 & 4,19 & 1,03 & \multirow{2}{*}{4,575} & \multirow{2}{*}{$0,000^{*}$} \\
\hline & Volo & 11 & 2,56 & 0,56 & & \\
\hline \multirow{2}{*}{ Mezomorphy } & Petanque Raffa & 10 & 4,72 & 0,64 & \multirow{2}{*}{$-2,222$} & \multirow{2}{*}{$0,039 *$} \\
\hline & Volo & 11 & 5,4 & 0,76 & & \\
\hline \multirow{2}{*}{ Ektomorphy } & Petanque Raffa & 10 & 2,09 & 0,28 & \multirow{2}{*}{0,284} & \multirow{2}{*}{0,78} \\
\hline & Volo & 11 & 2,05 & 0,32 & & \\
\hline
\end{tabular}
* $\mathrm{p}<0,05$

According to the t-test results in independent groups, the endomorphic and mesomorph measurements in women differ at a significant level according to petanque raffa and volo groups $(p<0,05)$, no significant differences were determined in other measurements between the groups $(p>0,05)$. While the mean values of the petanque raffa group for 
endomorphic measurements, which differ at a significant level, are higher than the volo group at a significant level; the mean values of the volo group in mesomorphic measurement is different from the mean values of the petanque raffa. No significant differences were detected between the petanque raffa and volo groups for the other measurements.

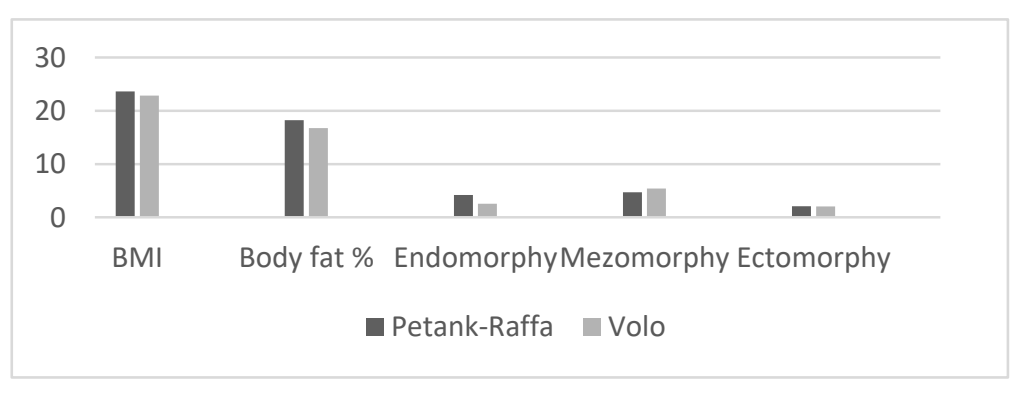

Graphic 2. Comparison of measurements according to groups in women

\section{Discussion and Conclusion}

The somatotype components that differ according to the sports done are important for aptitude tests in elite sports. There are important differences between the somatotype and body composition of elite players and sedentary people. Many studies show that players must be more mesomorphic and less endomorphic to reach success and high performance levels. In many sports, somatotype components are not homogenous. Especially in team sports, this may change according to the positions in which the players play. However, in individual sports, somatotype components have a more homogenous structure because higher sports performance is needed. The somatotype components may change according to the positions of the team players. Although Bocce is an individual sport, it has different game systems. It was observed that gymnasts had higher endomorphic components unlike volleyball players. When the basketball and volleyball players are compared with the players in other groups, they are taller and heavier; judo and hokey players are endo-mesomorphic; and other players are ecto-mesomorphic (Table 11).

In this study, volo players differed depending on their systems. For this reason, this is reflected in their somatotype profiles. While the somatotype component of the male volo group was balanced mesomorph, the male petanque and raffa group is mesomorph endomorphic; the somatotype component of the women volo group was endo-mesomorph; and the somatotype component of the other male petanque and raffa group players was mesomorph endomorphic. In this study, it was determined that the somatotype component of the Turkish Bocce Men-Women National Team was determined to be Endo-Mesomorphic.

A literature review was made, and it was determined that the somatotype components of the male volo group tennis players and the somatotype components of the archers, judo players and Water polo players overlap with the values determined in this study (Table 11).

Table 8. Somatotype profiles of players in different sports

\begin{tabular}{|c|c|c|c|c|c|c|c|}
\hline Author-year & Branch & $\begin{array}{l}\text { Number of } \\
\text { the subjects }\end{array}$ & Years (year) & Gender & $\begin{array}{l}\text { Height } \\
(\mathrm{cm})\end{array}$ & $\begin{array}{l}\text { Body } \\
\text { weight }(\mathrm{kg})\end{array}$ & Somatotype \\
\hline Abdollah et al. 2009 & Archery & 24 & $24 \pm 4$ & $\mathrm{M}$ & $181 \pm 6$ & $78 \pm 8$ & $3.45-4.5-2$. \\
\hline Sterkowicz K. 2009 & Archery & 30 & $23.3 \pm 2.9$ & $\mathrm{M}$ & - & - & $3.4-5.4-1.8$ \\
\hline Massidda et al. 2007 & Gymnastic & 64 & - & $\begin{array}{l}\text { F-42 } \\
\text { M-22 }\end{array}$ & - & - & $\begin{array}{l}1.7-4.2-2.7 \\
1.7-6.3-1.6\end{array}$ \\
\hline Pastuszak et al. 2016 & $\begin{array}{l}\text { Volleyball } \\
\text { Sedentary }\end{array}$ & $\begin{array}{l}22 \\
150 \\
\end{array}$ & $\begin{array}{l}21.6 \pm 1.5 \\
20.0 \pm 6.4 \\
\end{array}$ & $\begin{array}{l}\mathrm{F} \\
\mathrm{F} \\
\end{array}$ & $\begin{array}{l}177.3 \pm 6.2 \\
166.5 \pm 6.4 \\
\end{array}$ & $\begin{array}{l}71.0 \pm 6.5 \\
59.7 \pm 8.4 \\
\end{array}$ & $\begin{array}{l}4.5-3.4-2.8 . \\
5.1-3.6-2.8 \\
\end{array}$ \\
\hline Uluöz E. 2011 & Volleyball & 101 & $18,45 \pm 2,39$ & $\mathrm{~F}$ & $170,08 \pm 6,45$ & $58,06 \pm 7,05$ & $0,96-3.01-3.64$ \\
\hline Lal M. 2015 & $\begin{array}{l}\text { Football } \\
\text { Hockey }\end{array}$ & $\begin{array}{l}50 \\
50\end{array}$ & $\begin{array}{l}19.76 \pm 1.27 \\
20.0 \pm 1.78\end{array}$ & $\begin{array}{l}\mathrm{M} \\
\mathrm{M}\end{array}$ & $\begin{array}{l}170.75 \pm 6.13 \\
167.64 \pm 6.31 \\
\end{array}$ & $\begin{array}{l}60.16 \pm 7.42 \\
58.27 \pm 8.84 \\
\end{array}$ & $\begin{array}{l}1.50-3.44-3.39 \\
1.20-3.33-3.19 \\
\end{array}$ \\
\hline Ayan V. 2012 & Water polo & 16 & $22.81 \pm 5.25$ & $\mathrm{M}$ & $189.31 \pm 4.96$ & $97.26 \pm 9.39$ & $3.12-5.62-1.62$ \\
\hline Sterkowicz K. 2011 & Wrestling & $\begin{array}{l}\mathrm{A}-12 \\
\mathrm{~B}-11 \\
\end{array}$ & $\begin{array}{l}24.9 \pm 5.5 \\
20.6 \pm 0.97 \\
\end{array}$ & $\begin{array}{l}\mathrm{M} \\
\mathrm{M}\end{array}$ & $\begin{array}{l}175 \pm 0.09 \\
179 \pm 0.06 \\
\end{array}$ & $\begin{array}{l}81.8 \pm 14.29 \\
72.1 \pm 8.96 \\
\end{array}$ & $\begin{array}{l}2.0-6.6-1.2 \\
3.7-4.3-3.1 \\
\end{array}$ \\
\hline Lewandowska, J et al. 2011 & Judo & 13 & $18.4 \pm 3.1$ & & $178.6 \pm 8.2$ & $82.3 \pm 15.9$ & $3.5-5.9-1.8$ \\
\hline Bayios et al. 2006 & $\begin{array}{l}\text { Volleyball } \\
\text { Basketball } \\
\text { Handball } \\
\end{array}$ & 518 & - & - & - & - & $\begin{array}{l}3.4-2.7-2.9 \\
3.7-3.2-2.4 \\
4.2-4.7-1.8 \\
\end{array}$ \\
\hline Sánchez-Muñoz et al. 2007 & Tennis & 123 & $\begin{array}{l}16,2 \\
15,9\end{array}$ & $\begin{array}{l}\text { M-57 } \\
\text { F-66 }\end{array}$ & $\begin{array}{l}176.8 \pm 6.4 \\
165.4 \pm 6.3\end{array}$ & $\begin{array}{l}69.9 \pm 6.8 \\
59.9 \pm 6.2\end{array}$ & $\begin{array}{l}2.4-5.2-2.9 \\
3.8-4.6-2.4\end{array}$ \\
\hline
\end{tabular}

Bocce involves a more physical, spiritual and mental unity in terms of its application, and requires concentration and 
ability, which makes it different from the other sports branches (Pagnoni, M., 2010). It is believed that Volo players' being balanced mesomorph stems from the volo system requiring more sportive performance and muscular force when compared with the other systems.

As a conclusion, in this study, the somatotype profiles of the Turkish Bocce National Team players and the somatotype profiles of the players who competed in different systems in national team were determined. The somatotype profiles of the players who play in different systems varied. The somatotype components of Turkish Bocce Men-Women National Teams somatotype component were mesomorphic-endomorphic; men volo players were balanced mesomorph, which included more muscular force, when compared with petanque and raffa players; Women volo players were endo-mesomorph, Men-Women petanque and raffa players were mesomorph endomorphic. In this study, the purpose was to examine the somatotype profiles of Turkish Bocce National Team Players according to different game systems, and to determine the differences. Determining the anthropometric features of Bocce Players will be a guide in selecting skilled players in future.

\section{References}

Abdollah, S., Khosrow, E., \& Sajad, A. (2014). Comparison of anthropometric and functional characteristics of elite male iranian fencers in three weapons. International Journal Of Applied Sports Sciences, 26(1), 11-17. https://doi.org/10.24985/ijass.2014.26.1.11

Andreenko, E., \& Mladenova, S. (2015). Changes in somatotype characteristics in the middle-aged Bulgarian men. Nutricion Hospitalaria, 32(6), 2910-2915.

Ayan, V. (2012). The Study of The Somatotypes of the male athletes of the Turkish National Waterpolo Team. Prime Research on Medicine (Prom), 2(4), 110-115.

Ayan, V., Kaya, M., \& Erol, A. E. (2011). Men çocuklarının futbol branşı için somatotype ve performans özelliklerinin incelenmesi . Niğde Üniversitesi Beden Eğitimi Ve Spor Bilimleri Dergisi, 5(3), 27-31.

Ball, N., Nolan, E., \& Wheeler, K. (2011). Anthropometrical, physiological, and tracked power profiles of elite taekwondo athletes 9 weeks before the Olympic competition phase. J Strength Cond Res, 25, 2752-2763. https://doi.org/10.1519/JSC.0b013e31820d9f3f

Bayios, I. A., Bergeles, N. K., Apostolidis, N. G., Noutsos, K. S., \& Koskolou, M. D. (2006). Anthropometric, body composition and somatotype differences of Greek elite female basketball, volleyball and handball players. Journal Of Sports Medicine And Physical Fitness, 46(2), 271-280.

Bektaş, Y., Koca, B., \& Gültekin, Ö. T. (2007). Ağır, M, Akın, G. Women Basketbolcuların Antropometrik Özellikleri: Somatotype Ve Body Bileşimi Değerleri. Niğde Üniversitesi Beden Eğitimi ve Spor Bilimleri, 1(2), 21-22.

Bridge, C. A. (2014). Jonatas Ferreira da Silva Santos Helmi Chaabe`ne Willy Pieter Emerson Franchini. Physical and Physiological Profiles of Taekwondo Athletes. Sports Med, 44, 713-733.

https://doi.org/10.1007/s40279-014-0159-9

Carter, J. E. L. (1985). Somatotype as a criterion of the nutritional status in athletes. In Food, Physical Performance and Health. Johann Ambrosius Barth. Leipzig.

Carter, J. E. L., Ackland, T. R., Kerr, D. A., \& Stapff, A. B. (2005). Somatotype and size of elite female basketball players. Journal of Sports Sciences, 23, 1057-1063. https://doi.org/10.1080/02640410400023233

Carter, L. J. E., \& Heath, B. H. (1990). Somatotyping-Development and Aplications. New York: Cambridge University Press, 42.

Duquet, W., Cheturgue Van, B., \& Hebbelinckgn, H. (1977). Computer program for calculating the Heath-Carter anthropometric Somatotype. J. Sports. Med., 17(3), 255.

Günay, M., Tamer, K., \& Cicioğlu, İ. (2013). Spor Fizyolojisi ve Performans Ölçümü. 3. Bask1.Ankara, 559-587.

Gürses, Ç., \& Ogun, P. (1991). Sporda başarıyı etkileyen faktörler, sportif yetenek araştırma metodu, Turkish Spor Vakfi Yayınları.

Kim, H. B., Stebbins, C. L., \& Chai, J. H. (2011). Taekwondo training and fitness in female adolescents. J. Sports Sci., 29, 133-138. https://doi.org/10.1080/02640414.2010.525519

Lal, M. (2015). Comprative study of somatotype between football and hockey players. Indian Journal Of Applied Research, 5(5), 13-19.

Lewandowska, J., Buśko, K., Pastuszak, A., \& Boguszewska, K. (2011). Somatotype Variables Related to Muscle Torque and Power in Judoists. Journal of Human Kinetics, 30(1), 21-28. 
https://doi.org/10.2478/v10078-011-0069-y

Massidda, M., Toselli, S., Brasili, P., \& Calo, M. C. (2013). Somatotype of elite Italian gymnasts. Coll. Antropol, 37(3), 853-857.

Matıllas, M. M., Valadés, D., Hernández, E. H., Errano, F. O., Sjöström, M., Fernández, M. D ... Ortega, F. B. (2014). Anthropometric, body composition and somatotype characteristics of elite female volleyball players from the highest Spanish league. Journal of Sports Sciences, 32(2), 137-148.

https://doi.org/10.1080/02640414.2013.809472

Özer, K. (1993). Antropometri: Sporda Morfolojik Planlama. İstanbul: Kazancı Matbaacılık, 34.

Pagnoni, M. (2010). The joy of bocce. 3rd edition. Authur House. 1-29/ 60-61.

Parizkova, J. (1968). Body composition and physical fitness. Curr. Anthrop, 9, 273. https://doi.org/10.1086/200899

Pastuszak, A., Buśko, K., \& Kalka, E. (2016). Somatotype and body composition of volleyball players and untrained female students-reference group for comparison in sport. Anthropological Review, 79(4), 461-470. https://doi.org/10.1515/anre-2016-0033

Sánchez-Muñoz, C., Sanz, D., \& Zabala, M. (2007). Anthropometric characteristics, body composition and somatotype of elite junior tennis players. British Journal of Sports Medicine, 41(11), 793-799. https://doi.org/10.1136/bjsm.2007.037119

Sharma, S. S., \& Dixit, N. K. (1985). Somatotype of athletes and their performance. Int. J. Sports Med, 6(3), 161. https://doi.org/10.1055/s-2008-1025831

Sibila, M., \& Pori, P. (2009). Position-related differences in selected morphological body characteristics of top-level hand-ball players. Collegium Antropologicum, 33, 1079-1086.

Sterkowicz, K. (2009). Body composition and somatotype of the elite of polish fencers. Coll. Antropol, 33(3), 765-772.

Sterkowicz-Przybycień, K. L., Sterkowicz, S., \& Żarów, R. T. (2011). Somatotype, body composition and proportionality in Polish Top Greco-Roman Wrestlers. Journal of Human Kinetics, 28(1), 141-154. https://doi.org/10.2478/v10078-011-0031-z

Türkmen, M. (2011). Lawn Ball, Petanque, Raffa ve Volo oyun sistemleriyle; BOCCE Tanımlar, Tarihçe ve Oyun Kuralları. ANKARA. Neyir Yayınları - 1.Basım. 15-41.

Türkmen, M., Bozkuǵ, T., Kul, M., Özkan, A., \& Uslu, S. (2013). Türkiye bocce milli takımında yer alan genç sporcuların bazı fiziksel uygunluk ve vücut kompozisyonu özelliklerinin incelenmesi. 2. Uluslararası Bilim Kültür Ve Spor Kongresi, 49.

Uluöz, E. (2011). Elit altı Women volleyball oyuncularının fiziksel, anthropometric ve somatotype özelliklerinin oyun mevkilerine göre incelenmesi. Journal of New World Sciences Academy Sports Sciences, 6(4), $206-213$.

Zorba, E. (2012). Body Yapısı Ölçüm Yöntemleri ve Şişmanlıkla Başa Çıkma.Morpa Ofset. İstanbul, $140-153$.

Zorba, E., \& Ziyagil, A. (1995). Body komposizyonu ve ölçüm metodları, Trabzon:gen matbaa.

\section{Copyrights}

Copyright for this article is retained by the author(s), with first publication rights granted to the journal.

This is an open-access article distributed under the terms and conditions of the Creative Commons Attribution license which permits unrestricted use, distribution, and reproduction in any medium, provided the original work is properly cited. 